\title{
Optimasi Aristoflex® AVC dan Propilen Glikol Gel Tabir Surya Rimpang Kunyit dengan Metode Desain
} Faktorial

\section{Optimization of Aristoflex ${ }^{\circledR}$ AVC and Propylene Glycol in Turmeric (Curcuma domestica) Rhizome Extract Gel}

Arsiaty Sumule ${ }^{1 *}$, Gunawan Pamudji ${ }^{1}$, Endang Diyah Ikasari ${ }^{2}$

${ }^{1}$ Program Studi Magister Ilmu Farmasi, Fakultas Farmasi, Universitas Setia Budi Surakarta, Surakarta, Indonesia

${ }^{2}$ Program Studi Profesi Apoteker, Sekolah Tinggi Ilmu Farmasi Yayasan Pharmasi Semarang, Semarang, Indonesia

*Corresponding author: sumulearsiaty@ gmail.com

Submitted: 17 Desember 2020

Accepted: 6 April 2021

Published: 29 Agustus 2021

\begin{abstract}
Background: Turmeric (Curcuma domestica) contains curcumin suitable for use as a skin protector from ultraviolet $(U V)$. Topical sunscreens need to be developed, which is a gel, the most stable preparation. Optimization is more profitable than trial and error methods in terms of cost, time, and accuracy of results. Objective: To determine the effect of combining Aristoflex® AVC and propylene glycol on the physical properties of turmeric rhizome extract gel, as well as the optimum turmeric rhizome extract gel formula and the effect of combining Aristoflex@ AVC and propylene glycol on the SPF value of turmeric rhizome extract gel. Methods: Gel had been made into four formulas with the composition of Aristoflex ${ }^{\circledR}$ AVC $1 \%$ and $3 \%$ and propylene glycol $5 \%$ and $10 \%$. The parameters were spreadability, adhesion, viscosity, and SPF values calculated in vitro using spectrophotometer. The results had been optimized by factorial design using Design Expert 7.1.5. Results: The combination of Aristoflex® AVC and propylene glycol had affected spreadability, adhesion, viscosity, and SPF value. The results had shown that the optimum formula of turmeric rhizome extract gel in the combination of Aristoflex@ AVC and propylene glycol $1.68 \%$ and 9,87\% respectively, so that the spreadability was $5.1 \mathrm{~cm}$, adhesion was 2.018 seconds, viscosity was 110.008 dPas, and SPF value was 11.935. Conclusion: Combination of Aristoflex ${ }^{\circledR} A V C$ and propylene glycol affected on the spreadability, adhesion, viscosity, and SPF value of the turmeric rhizome extract gel. The proportion of Aristoflex® AVC $1.68 \%$ and propylene glycol $9.87 \%$ was the optimum formula.
\end{abstract}

Keywords: aristoflex® AVC, gel, propylene glycol, turmeric, sunscreen

\begin{abstract}
Abstrak
Pendahuluan: Kunyit (Curcuma domestica) mengandung kurkumin yang cocok digunakan sebagai pelindung kulit dari sinar ultraviolet (UV). Produk tabir surya topikal perlu dikembangkan, salah satunya gel, sediaan paling stabil dan tidak menunjukkan pemisahan fase. Optimasi lebih menguntungkan dibandingkan metode trial and error dari segi biaya, waktu, dan keakuratan hasil. Tujuan: Mengetahui pengaruh kombinasi Aristoflex® AVC dan propilen glikol pada sifat fisik gel ekstrak rimpang kunyit, mengetahui formula gel ekstrak rimpang kunyit yang optimum, dan mengetahui pengaruh kombinasi Aristoflex ${ }^{\circledR}$ AVC dan propilen glikol pada nilai SPF dari sediaan gel ekstrak rimpang kunyit. Metode: Gel dibuat empat formula dengan komposisi Aristoflex® AVC $1 \%$ dan 3\% dan propilen glikol 5\% dan 10\%. Parameter yang digunakan meliputi daya sebar, daya lekat, viskositas, dan nilai SPF yang dihitung secara in vitro menggunakan spektrofotometri. Hasil uji dioptimasi dengan metode desain faktorial menggunakan Design Expert 7.1.5. Hasil: Kombinasi Aristoflex ${ }^{\circledR}$ AVC dan propilen glikol berpengaruh terhadap daya sebar, daya lekat, viskositas dan nilai SPF yang dihasilkan. Hasil penelitian menunjukkan formula optimum gel ekstrak rimpang kunyit pada kombinasi Aristoflex® AVC dan propilen glikol masing-masing 1,68\% dan 9,87\% sehingga diperoleh nilai daya sebar 5,1 cm, daya lekat 2,018 detik, viskositas 110,008 dPas, dan nilai SPF 11,935. Kesimpulan: Kombinasi Aristoflex® AVC dan propilen glikol memberikan
\end{abstract}


pengaruh pada daya sebar, daya lekat, viskositas, dan nilai SPF sediaan gel ekstrak rimpang kunyit. Proporsi Aristoflex ${ }^{\circledR}$ AVC 1,68\% dan propilen glikol 9,87\% merupakan formula optimum gel ekstrak rimpang kunyit.

Kata kunci: aristoflex® AVC, gel, kunyit, propilen glikol, tabir surya

\section{PENDAHULUAN}

Tabir surya (sunscreen) memiliki peran penting dalam melindungi kulit karena paparan radiasi sinar UV sangat berbahaya bagi kulit (Adithi dkk., 2017), namun memiliki keterbatasan, diantaranya tabir surya bahan kimia (chemical filter) dilaporkan sebagai alergen utama menyebabkan fotoalergi (Murphy, 2014) dan menyebabkan gejala alergi akut dan kronis (Skotarczak dkk., 2015). Titanium dioksida sangat kecil, mampu menembus ke dalam kulit dan UVA dapat menginduksi mutasi DNA yang memicu terjadinya kanker akibat oksigen reaktif yang berlebihan merusak protein dan lipid. Filter anorganik mengganggu daya serap perkutan dan endokrin yang menyebabkan penyumbatan poripori kulit menyebabkan jerawat (Skotarczak dkk., 2015).

Keterbatasan ini memicu alternatif tabir surya yang aman dan terjangkau, salah satunya penggunaan bahan alam. Rimpang kunyit diketahui memiliki kandungan kurkumin yang dapat diterapkan sebagai tabir surya yang efektif untuk fotoinflamasi, didukung penelitian bahwa kurkumin dapat menghambat ekspresi COX-2 dengan menekan p38 MAPK (Mitogen-Activated Protein Kinases) dan JNK (c-Jun NH2 terminal Kinase) dalam sel HaCaT (human keratinocytes) yang diradiasi UVB (Cho dkk., 2005). Penelitian terbaru melaporkan bahwa kurkumin efektif melindungi sel terhadap fotoaging yang diinduksi oleh UVA pada fibroblast kulit manusia, mengurangi akumulasi ROS (reactive oxygen species) yang diinduksi UVA dengan cara memulihkan aktivitas enzim antioksidan, dan mengurangi tekanan/stress retikulum endoplasma (Liu dkk., 2018).

Produk tabir surya topikal perlu dikembangkan, salah satunya gel, sediaan paling stabil dan tidak menunjukkan pemisahan fase (Anggraeni, 2008). Hasil yang serupa juga dikemukakan oleh Wardiyah (2015) bahwa gel paling stabil secara fisik dibandingkan krim dan salep selama uji stabilitas empat minggu. Gelling agent yang mudah digunakan yakni Aristoflex ${ }^{\circledR}$ AVC memberikan formulasi hasil baik tanpa adanya pengemulsi tambahan memiliki kompatibilitas yang baik dengan pelarut organik (etanol, aseton), stabil terhadap radiasi UV, memiliki sifat sensorik yang baik (terasa nyaman di kulit dan transparan). Humektan dalam sediaan tabir surya mutlak ada sebagai pelembab karena dapat mengurangi evaporasi air dari kulit untuk mengurangi efek paparan sinar ultraviolet (Yuliani, 2010).

Metode trial and error sudah ditinggalkan karena kurang efisien, mahal, lama, dan seringkali gagal sehingga perlu digunakan teknik optimasi yang lebih menguntungkan dari segi biaya, waktu, dan keakuratan hasil, salah satunya menggunakan desain faktorial. Penggunaan desain faktorial untuk mengembangkan komposisi bahan yang dioptimasi, mengetahui interaksi antar faktor pada percobaan, serta dapat menentukan efek utama dan efek interaksi pada percobaan yang dilakukan. Kombinasi Aristoflex ${ }^{\circledR}$ AVC sebagai gelling agent serta propilen glikol dalam proporsi campuran yang optimal diharapkan mampu memberikan sediaan gel berkualitas yang memenuhi persyaratan fisik yang baik dan mampu memberikan perlindungan yang optimal sebagai sediaan tabir surya.

Penelitian ini bertujuan untuk mengetahui pengaruh kombinasi Aristoflex ${ }^{\circledR}$ AVC dan propilen glikol pada sifat fisik gel ekstrak rimpang kunyit, mengetahui formula gel ekstrak rimpang kunyit yang optimum, dan mengetahui pengaruh kombinasi Aristoflex ${ }^{\circledR}$ AVC dan propilen glikol pada nilai SPF dari sediaan gel ekstrak rimpang kunyit.

\section{BAHAN DAN METODE}

\section{Bahan}

Ekstrak rimpang kunyit yang diperoleh dari PT. Tri Raharja, Aristoflex ${ }^{\circledR}$ AVC (Clariant), gliserin (Ecogreen Oleochemicals), propilen glikol (DOW Chemical Pacific), nipagin (Ueno), nipasol (Ueno), aqua purificata (Zenith), dan etanol pa (Merck).

\section{Alat}

Alat-alat yang digunakan antara lain timbangan (Lutron GM-500), neraca analitik (XT 120A), viskometer (Rion VT-04F), spektrofotometer UV-VIS (Hitachi U-2900), alat uji daya sebar, daya lekat, mortar, stamper.

Metode

Optimasi dilakukan dengan metode desain faktorial, dimana Aristoflex® AVC dan propilen glikol merupakan parameter yang akan diteliti pengaruhnya terhadap kualitas gel yang diwakili oleh viskositas, daya sebar, daya lekat, dan nilai SPF yang kemudian disebut 
respon. Data hasil percobaan meliputi viskositas, daya lekat, daya sebar, dan nilai SPF dimasukkan ke dalam persamaan matematis untuk model desain faktorial sehingga diperoleh contour plot. Berdasarkan contour plot parameter viskositas, daya lekat, daya sebar, dan nilai SPF dijadikan satu (superimposed contour plot) sehingga dapat ditentukan daerah optimum dengan sifat gel yang dikehendaki. Pengolahan data optimasi menggunakan software Design Expert ${ }^{\circledR}$ (Stat-Ease Inc, Minneapolis, MN, USA) versi 7.1.5.

\section{Pembuatan gel ekstrak rimpang kunyit}

Aqua purificata (suhu $30-40^{\circ} \mathrm{C}$ ) dimasukkan ke dalam mortir lalu ditambah Aristoflex ${ }^{\circledR}$ AVC, kemudian dilakukan pengadukan (campuran I). Nipagin dan nipasol dimasukkan ke dalam wadah, ditambahkan aqua purificata, dipanaskan, dan diaduk homogen hingga tidak terlihat butiran kasar, lalu gliserin dan propilen glikol ditambahkan. Ekstrak rimpang kunyit ditambahkan dan diaduk hingga homogen (Campuran II). Pencampuran antara campuran I dan campuran II diaduk perlahan dalam mortir hingga membentuk gel. Formula dapat dilihat pada Tabel 1.

Tabel 1. Rancangan formula gel ekstrak rimpang kunyit berdasarkan desain faktorial (b/b\%)

\begin{tabular}{ccccc}
\hline Bahan & F1 & F2 & F3 & F4 \\
\hline $\begin{array}{c}\text { Ekstrak } \\
\text { rimpang } \\
\text { kunyit }\end{array}$ & 1 & 1 & 1 & 1 \\
$\begin{array}{c}\text { Aristoflex } \\
\text { AVC }\end{array}$ & 1 & 3 & 1 & 3 \\
Gliserin & 15 & 15 & 15 & 15 \\
Propilen & 10 & 10 & 5 & 5 \\
glikol & & & & \\
Nipagin & 0,2 & 0,2 & 0,2 & 0,2 \\
Nipasol & 0,2 & 0,2 & 0,2 & 0,2 \\
Aqua & sampai & sampai & sampai & sampai \\
purificata & 100 & 100 & 100 & 100 \\
\hline
\end{tabular}

\section{Uji viskositas}

Spindel 2 dipasang pada viskometer (Rion VT04F). Mangkuk diisi sampel gel, diletakkan di bagian bawah alat viskometer, kemudian spindel diturunkan hingga terendam dalam sampel gel. Spindel harus berada pada posisi tengah, lalu viskometer dinyalakan. Spindel dibiarkan berputar selama 30 detik, kemudian nilai yang ditunjuk oleh jarum display dicatat setelah stabil (Yuliani, 2010).

\section{Uji daya sebar}

Pemeriksaan dilakukan dengan menekan dua lempengan kaca pada $0,5 \mathrm{~g}$ sediaan, kemudian ditambahkan beban anak timbang $50 \mathrm{~g}$ sebagai beban tambahan, dan didiamkan selama 1 menit sesudah itu dicatat diameter gel yang menyebar. Diameter penyebaran formula yang diambil dari panjang rata-rata diameter dari beberapa sisi (Silalahi dkk., 2015).

\section{Uji daya lekat}

Pengujian daya lekat gel dilakukan dengan cara sebanyak 0,2 g gel dan diletakkan di atas gelas objek. Diletakkan gelas objek yang lain di atas gel tersebut, ditekan dengan beban $500 \mathrm{~g}$ selama 5 menit, lalu beban tersebut diangkat. Beban samping dilepaskan seberat 20 gram, maka gelas objek akan bergeser berlawanan dan dicatat waktunya hingga kedua gelas objek terlepas (Silalahi dkk., 2015). Ilustrasi uji daya lekat dapat dilihat pada Gambar 1.

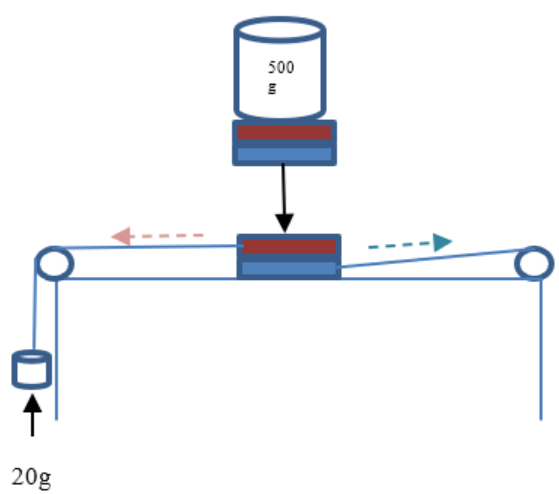

Gambar 1. Ilustrasi uji daya lekat

\section{Pengujian nilai SPF}

Metode dapat dimodifikasi yaitu sampel gel ekstrak rimpang kunyit, basis gel, kontrol positif gel (SPF 30) diambil sebanyak 0,5 g kemudian dimasukkan ke dalam labu ukur $25 \mathrm{~mL}$ dan diencerkan dengan etanol pa. Larutan diultrasonifikasi selama 5 menit, kemudian disaring. Larutan yang diperoleh diukur dengan spektrofotometer UV-Vis pada panjang gelombang 290 - $320 \mathrm{~nm}$, blanko yang digunakan yaitu etanol pa. Setiap interval 5, nilai absorbansi dicatat, kemudian nilai absorbansi dihitung nilai SPF dengan menggunakan persamaan Mansur berikut (Mokodompit dkk., 2013). Data normalized product function yang digunakan pada kalkulasi SPF ditampilkan pada Tabel 2.

$$
\mathrm{SPF}=C F x \sum_{290}^{320} E(\lambda) x I(\lambda) x \text { abs }(\lambda)
$$

Keterangan:

CF: Faktor koreksi (10)

EE: Spekrum efek eritema

I: Spektrum intensitas matahari

Abs: Absorbansi sampel 
Tabel 2. Normalized product function digunakan pada kalkulasi SPF (Khan, 2018)

\begin{tabular}{ccc}
\hline No. & $\begin{array}{c}\text { Panjang } \\
\text { gelombang }(\mathrm{nm})\end{array}$ & EE x I \\
\hline 1 & 290 & 0,0150 \\
2 & 295 & 0,0817 \\
3 & 300 & 0,2874 \\
4 & 305 & 0,3278 \\
5 & 310 & 0,1864 \\
6 & 315 & 0,0839 \\
7 & 320 & 0,0180 \\
\hline
\end{tabular}

\section{Analisis data}

Formula optimum ditentukan berdasarkan goal dan bobot masing-masing parameter yang dapat dilihat pada Tabel 3. Parameter yang dianalisis akan didapatkan formula optimum sesuai target yang diinginkan terhadap masing-masing respon.

Tabel 3. Nilai dan bobot parameter optimum

\begin{tabular}{|c|c|c|c|c|}
\hline Nama & Goal & $\begin{array}{l}\text { Limit } \\
\text { lower }\end{array}$ & $\begin{array}{l}\text { Limit } \\
\text { upper }\end{array}$ & Importance \\
\hline $\begin{array}{c}\text { Aristoflex }{ }^{\circledR} \\
\text { AVC }\end{array}$ & in range & $1 \%$ & $3 \%$ & 3 \\
\hline $\begin{array}{l}\text { Propilen } \\
\text { glikol }\end{array}$ & in range & $5 \%$ & $10 \%$ & 3 \\
\hline Daya sebar & $\begin{array}{l}\text { is target } \\
\quad=5,1\end{array}$ & $5 \mathrm{~cm}$ & $\begin{array}{c}6,38 \\
\mathrm{~cm}\end{array}$ & 5 \\
\hline Daya lekat & Maximize & $\begin{array}{l}1,13 \\
\text { detik }\end{array}$ & $\begin{array}{l}3,43 \\
\text { detik }\end{array}$ & 4 \\
\hline Viskositas & $\begin{array}{l}\text { is target } \\
=110\end{array}$ & $\begin{array}{c}100 \\
\text { dPas }\end{array}$ & $\begin{array}{c}200 \\
\text { dPas }\end{array}$ & 5 \\
\hline SPF & in range & 11,13 & 16,10 & 3 \\
\hline
\end{tabular}

Nilai percobaan respon daya sebar, daya lekat, viskositas, dan nilai SPF digunakan untuk melengkapi persamaan umum sebagai berikut:

$\mathrm{Y}=\mathrm{b}_{0}+\mathrm{b}_{\mathrm{a}} \mathrm{X}_{\mathrm{A}}+\mathrm{b}_{\mathrm{b}} \mathrm{X}_{\mathrm{B}}+\mathrm{b}_{\mathrm{ab}} \mathrm{X}_{\mathrm{A}} \mathrm{X}_{\mathrm{B}}$

$\mathrm{Y}$ : respon yang diamati

$\mathrm{X}_{\mathrm{A}}$ : aras bagian $\mathrm{A}$

$\mathrm{X}_{\mathrm{B}}$ : aras bagian $\mathrm{B}$

$\mathrm{b}_{0}, \mathrm{~b}_{\mathrm{a}}, \mathrm{b}_{\mathrm{b}}, \mathrm{b}_{\mathrm{ab}}$ : koefisien
Persamaan umum yang diperoleh merupakan hubungan antara faktor dan respon. Hasil dari perhitungan ini dibuat contour plot dengan menggunakan program Design Expert@ (Stat-Ease Inc, Minneapolis, MN, USA) versi 7.1.5. Contour plot digabungkan menjadi overlay plot untuk mengetahui daerah komposisi optimum Aristoflex ${ }^{\circledR}$ AVC dan propilen glikol.

Verifikasi persamaan yang diperoleh dengan metode desain faktorial dilakukan dengan (one sample T-test) (confidence interval 95\%, uji 2 sisi nilai $\mathrm{p}=$ 0,005 ) terhadap parameter yang diuji (viskositas, daya lekat, daya sebar, dan nilai SPF) antara nilai teoritis dengan hasil percobaan, persamaan terverifikasi jika tidak terdapat perbedaan yang bermakna antara nilai hasil teoritis dan hasil percobaan formula optimum.

\section{HASIL DAN PEMBAHASAN Organoleptis}

Organoleptis suatu sediaan akan mempengaruhi kenyamanan dalam penggunaan pada kulit (Juwita dkk., 2013). Pemeriksaan organoleptis meliputi tekstur, warna, dan bau diamati secara visual. Sediaan gel menghasilkan bau khas rempah kunyit, berwarna kuning, bertekstur halus, dan saat dioleskan tidak meninggalkan residu warna. Dari semua formula yang dibuat menghasilkan homogenitas yang homogen, tidak terdapat partikel-partikel yang dapat teraba dan terdapat persamaan warna. Ada tingkat daya tarik yang tinggi di antara fase terdispersi dan medium berair sehingga gel tetap sama rata saat berdiri sendiri serta membentuk gel dan tidak dapat mengendap secara bebas (Rathod \& Metha, 2015). Homogenitas merupakan faktor penting karena dapat berpengaruh terhadap distribusi obat. Sediaan topikal, seperti gel, dikatakan homogen bila tidak adanya partikel atau bahan kasar yang dapat teraba dan terdapat persamaan warna (Syamsuni, 2005). Hasil pengamatan sediaan fisik gel dapat dilihat pada Tabel 4.

Tabel 4. Hasil pengamatan sediaan fisik gel ekstrak rimpang kunyit

\begin{tabular}{llllll}
\hline \multirow{2}{*}{ Parameter uji } & \multicolumn{5}{c}{ Hasil Pemeriksaan } \\
\cline { 2 - 5 } Organoleptis & F1 & F2 & F3 & F4 \\
& $\begin{array}{l}\text { Gel transparan, bau } \\
\text { khas rempah kunyit, } \\
\text { dan berwarna kuning. }\end{array}$ & $\begin{array}{l}\text { kel transparan, bau } \\
\text { dan berwarna kuning. }\end{array}$ & $\begin{array}{l}\text { Gel transparan, bau } \\
\text { dan berwarna kuning. }\end{array}$ & $\begin{array}{l}\text { transparan, bau berwarna kuning. } \\
\text { dan bempan }\end{array}$ \\
Homogenitas & Homogen & Homogen & Homogen & Homogen \\
Daya sebar (cm) & $6,38 \pm 0,24$ & $2,74 \pm 0,04$ & $5,10 \pm 0,07$ & $2,72 \pm 0,03$ \\
Daya lekat (detik) & $1,47 \pm 0,32$ & $3,43 \pm 0,31$ & $1,20 \pm 0,10$ & $2,97 \pm 0,81$ \\
Viskositas (dPas) & $10,33 \pm 1,53$ & $300,00 \pm 1,00$ & $18,00 \pm 1,00$ & $306,67 \pm 2,89$ \\
SPF & $11,61 \pm 0,70$ & $12,67 \pm 0,20$ & $11,13 \pm 0,44$ & $15,12 \pm 1,55$ \\
\hline
\end{tabular}

Keterangan:

F1: Formula gel Aristoflex® AVC 1\%: propilen glikol 10\% F3: Formula gel Aristoflex® AVC 1\%: propilen glikol 5\%

F2: Formula gel Aristoflex ${ }^{\circledR}$ AVC 3\%: propilen glikol 10\% F4: Formula gel Aristoflex® AVC 3\%: propilen glikol 5\% 


\section{Daya sebar}

$\mathrm{Y}=6,76-1,51 \mathrm{~A}-0,07 \mathrm{~B}+0,05 \mathrm{AB}$

$\mathrm{A}=$ Aristoflex ${ }^{\circledR} \mathrm{AVC} ; \mathrm{B}=$ propilen glikol; dan $\mathrm{AB}=$ interaksi antara komponen $\mathrm{A}$ dan $\mathrm{B}$.

Sediaan dikatakan baik dan lebih disukai bila dapat menyebar dengan mudah di kulit dan nyaman digunakan. Daya sebar 5 - 7 cm menandakan konsistensi sediaan semisolid yang nyaman digunakan (Yati dkk., 2018). Nilai daya sebar dapat dilihat pada Tabel 4.

Hasil koefisien faktor Aristoflex ${ }^{\circledR} \operatorname{AVC}(-1,51)$ menunjukkan peningkatan Aristoflex ${ }^{\circledR}$ AVC dapat menurunkan nilai daya sebar. Aristoflex ${ }^{\circledR}$ AVC sebagai polimer pembentuk gel meningkatkan kekakuan karena adanya jaringan yang dibentuk oleh interlinking partikel/monomer-monomer pembentuk gel. Gel lebih kaku karena kepadatan ikatan fisik yang lebih tinggi dan terikat secara kovalen yang membuat penyebaran rendah (Rathod \& Metha, 2015). Nilai koefisien propilen glikol $-0,07$ menunjukkan peningkatan propilen glikol dapat menurunkan nilai daya sebar. Propilen glikol mempunyai karakteristik yang spesifik pada sistem gel dimana berefek memperkecil daya sebar, hal tersebut mungkin disebabkan sifat viskoelastik dari propilen glikol yang muncul di sini (Yuliani, 2010). Nilai koefisien yang dihasilkan kombinasi faktor Aristoflex ${ }^{\circledR}$ AVC dan propilen glikol $(+0,05)$ menunjukkan bahwa faktor Aristoflex® AVC dan propilen glikol memiliki peran dalam meningkatkan respon daya sebar. Molekul Aristoflex ${ }^{\circledR}$ AVC memiliki konformasi lipatan kompleks dalam bentuk kering. Interaksi dengan propilen glikol dimana Aristoflex $®$ AVC terdispersi membuat perubahan konformasi yakni molekul-molekulnya sedikit terentang yang menyebabkan sediaan mudah menyebar (Boer dkk., 2015). Contour plot (Gambar 2) menunjukkan bahwa interaksi konsentrasi rendah Aristoflex ${ }^{\circledR}$ AVC dan konsentrasi tinggi propilen glikol dapat meningkatkan nilai daya sebar. Interaksi konsentrasi tinggi Aristoflex ${ }^{\circledR}$ AVC dan konsentrasi level rendah dan tinggi dari propilen glikol dapat menurunkan nilai daya sebar, hal ini terlihat bahwa interaksi Aristoflex® AVC dan propilen glikol dapat memberikan pengaruh terhadap nilai daya sebar.
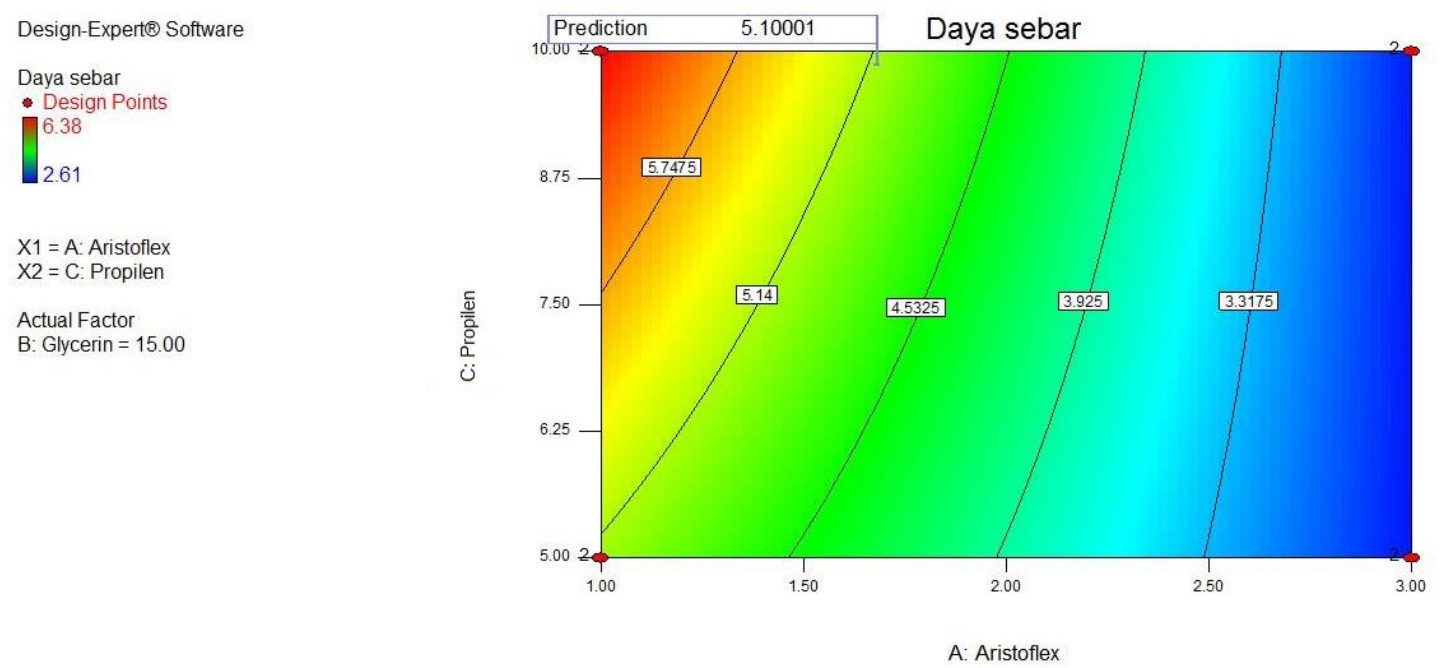

Gambar 2. Contour plot Aristoflex® AVC dan propilen glikol daya sebar sediaan gel ekstrak rimpang kunyit

\section{Daya lekat}

$\mathrm{Y}=-0,09+1,75 \mathrm{~A}+0,14 \mathrm{~B}-0,19 \mathrm{AB}$

$\mathrm{A}=$ Aristoflex ${ }^{\circledR} \mathrm{AVC} ; \mathrm{B}=$ propilen glikol; dan $\mathrm{AB}=$ interaksi antara komponen $\mathrm{A}$ dan $\mathrm{B}$.

Koefisien faktor $(+1,75)$ menunjukkan peningkatan Aristoflex ${ }^{\circledR}$ AVC dapat meningkatkan daya lekat. Aristoflex® AVC membentuk jaringan mikrogel dengan struktur ikatan silang yang sangat kuat dari polimer dalam matriks air, sehingga menjadi kental dan lengket, sebab itu mampu meningkatkan daya lekatnya (Lee dkk., 2016; Varges dkk., 2019). Nilai koefisien yang dihasilkan propilen glikol $+0,14$ menunjukkan P-ISSN: 2406-9388 E-ISSN: 2580-8303 propilen glikol meningkatkan respon daya lekat. Propilen glikol menghasilkan daya rekat secara simultan pada hidrogel melalui pembentukan ikatan hidrogen yang memiliki korelasi langsung dengan sifat daya lekatnya. Propilen glikol diketahui sebagai donor hidrogen dan sifat adhesif yang kuat karena melalui ikatan hidrogen. Propilen glikol melakukan peran agen pengikat silang parsial melalui ikatan hidrogen yang menyebabkan struktur jaringan pengikat silang lebih padat yang membuat daya lekatnya semakin tinggi (Dana dkk, 2013). 
Nilai koefisien yang dihasilkan pada Aristoflex ${ }^{\circledR}$ AVC dan propilen glikol $(-0,19)$ menunjukkan bahwa Aristoflex ${ }^{\circledR}$ AVC dan propilen glikol menurunkan respon daya lekat. Komponen polimer secara signifikan mempengaruhi tingkat keterikatan dan kelekatan. Tingkat hubungan silang dalam sistem polimer mempengaruhi mobilitas rantai. Seiring kepadatan ikatan silang meningkat, mobilitas rantai menurun yang berdampak mengurangi kekuatan kelekatannya. Fleksibilitas rantai sangat penting untuk daya lekat
(Singh dkk., 2013). Contour plot (Gambar 3) menggambarkan semakin rendah konsentrasi propilen glikol yang berinteraksi dengan konsentrasi rendah Aristoflex ${ }^{\circledR}$ AVC berdampak pada penurunan daya lekat. Interaksi level bawah dan level atas dari faktor propilen glikol terhadap level rendah Aristoflex® AVC dapat menurunkan daya lekat. Bila konsentrasi Aristoflex ${ }^{\circledR}$ AVC dan propilen glikol semakin besar dapat meningkatkan nilai daya lekat. Nilai daya lekat dapat dilihat pada Tabel 4.
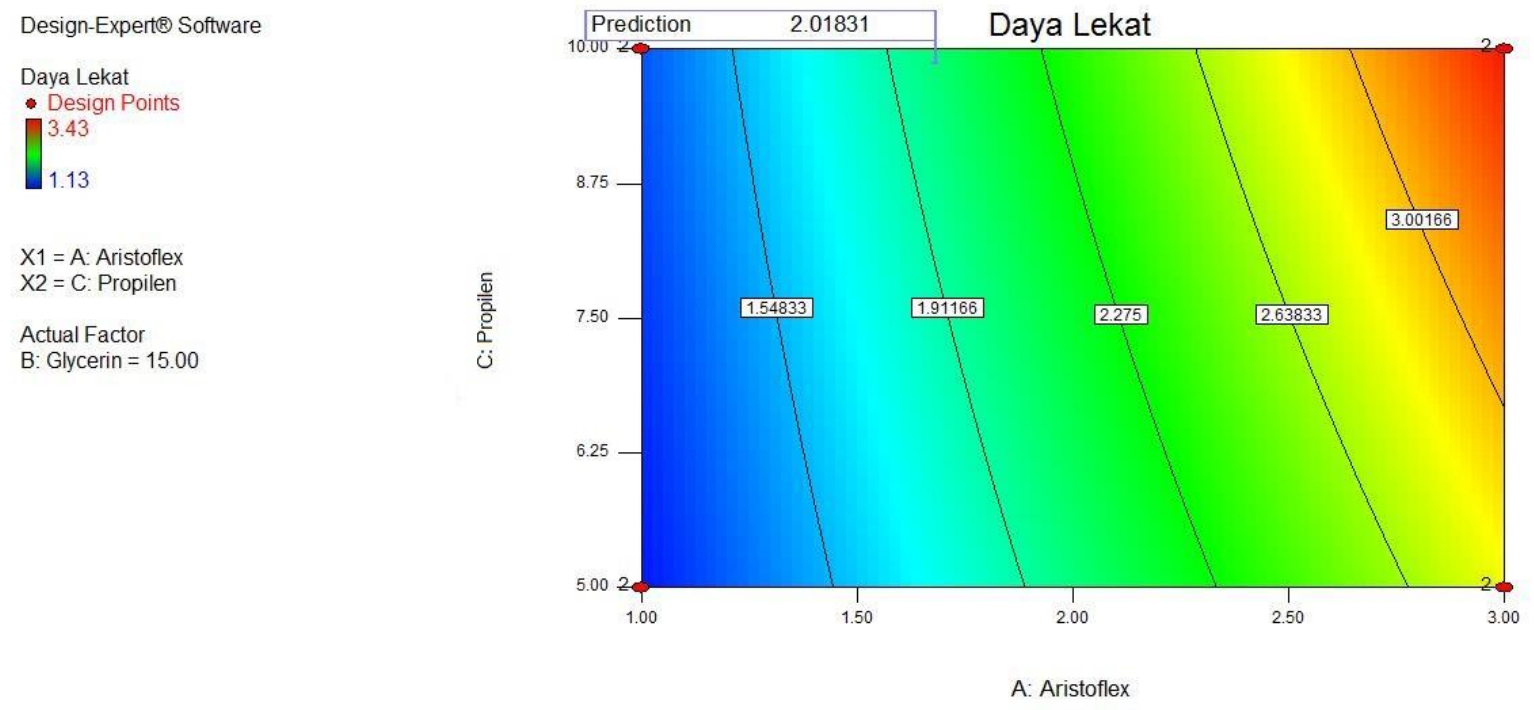

Gambar 3. Contour plot Aristoflex ${ }^{\circledR}$ AVC dan propilen glikol daya lekat sediaan gel ekstrak rimpang kunyit

\section{Viskositas}

$\mathrm{Y}=-97,19+100,45 \mathrm{~A}-0,36 \mathrm{~B}+1,43 \mathrm{AB}$

$\mathrm{A}=$ Aristoflex ${ }^{\circledR} \mathrm{AVC} ; \mathrm{B}=$ propilen glikol; dan $\mathrm{AB}=$ interaksi antara komponen $\mathrm{A}$ dan $\mathrm{B}$.

Koefisien faktor Aristoflex ${ }^{\circledR}$ AVC $(+100,45)$ menunjukkan peningkatan Aristoflex ${ }^{\circledR}$ AVC dapat meningkatkan viskositas. Polimer yang hidrofil membuat kontak semakin banyak dan lebih dekat dengan air atau media berair, yang menyebabkan molekul air bergerak lebih lambat dan meningkatkan viskositas (Sinko, 2011). Koefisien faktor yang dihasilkan propilen glikol adalah $+0,36$ menunjukkan propilen glikol meningkatkan respon viskositas karena memiliki gugus hidroksil yang pada dasarnya dapat berpartisipasi dalam ikatan hidrogen (Rhys dkk., 2016) dimana menurut Contreras \& Sanchez (2002) ikatan hidrogen dapat meningkatkan ikatan silang antar rantai sehingga meningkatkan viskositas. Koefisien faktor yang dihasilkan kombinasi Aristoflex® AVC dan propilen glikol adalah $+1,43$ menunjukkan peningkatan respon viskositas. Dalam aplikasi yang diinginkan peningkatan viskositas tujuannya untuk meningkatkan jarak rantai ujung ke ujung di bawah pemuatan beban yang diberikan. Dalam pengembangan polimer, beban berasal dari interaksi polimer dan pelarut. Jarak ujung ke ujung lebih panjang jika rantai polimer lebih panjang dan lebih banyak berinteraksi dengan pelarut seperti air atau media berair, salah satunya propilen glikol (Sinko, 2011). Selain itu, peningkatan viskositas ini dapat dijelaskan dengan mekanisme gelasi, yaitu reaksi vinil pirolidon dengan gugus hidroksil propilen glikol mengarah pada pembentukan ikatan hidrogen. Jumlah ikatan hidrogen yang lebih tinggi akibat interaksi Aristoflex ${ }^{\circledR}$ AVC dan propilen glikol menghasilkan viskositas yang lebih tinggi (Peneva dkk., 2017). Contour plot (Gambar 4) Aristoflex® AVC level rendah berinteraksi dengan propilen glikol level rendah hingga level tinggi dapat menurunkan viskositas, bila konsentrasi Aristoflex® AVC semakin besar maka akan meningkatkan viskositas. 

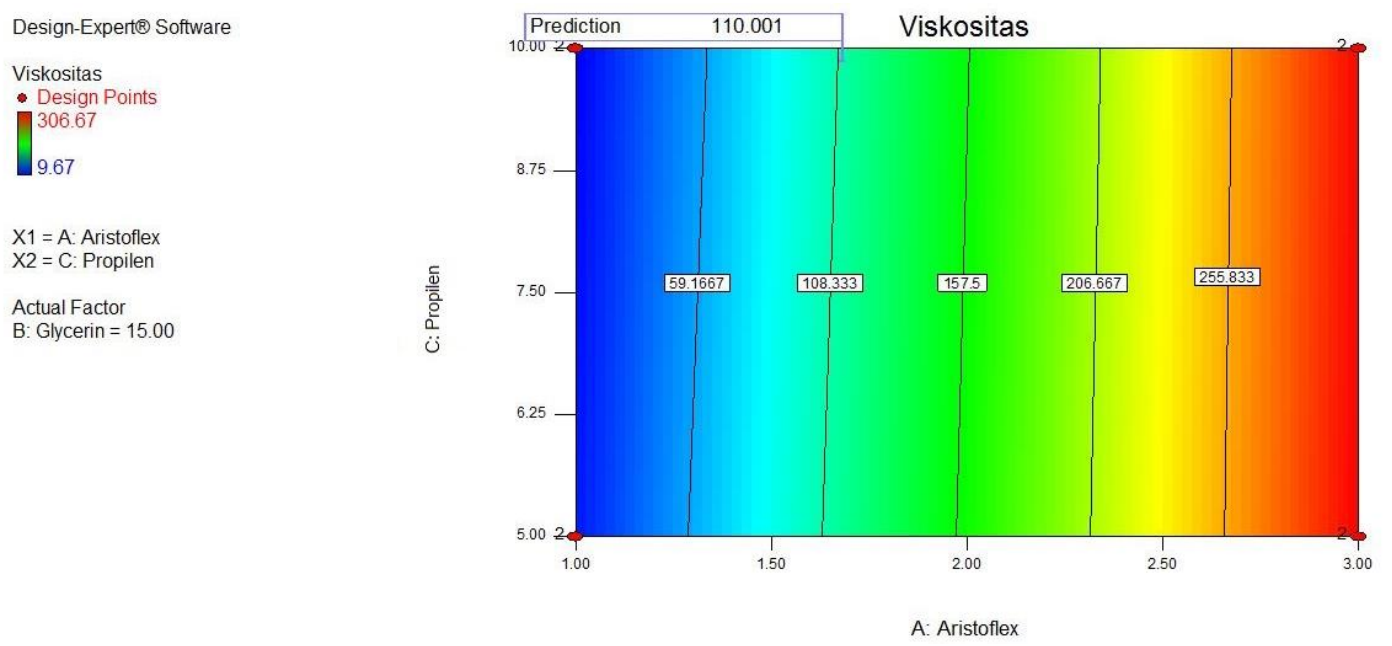

Gambar 4. Contour plot Aristoflex® AVC dan propilen glikol viskositas sediaan gel ekstrak rimpang kunyit

\section{SPF}

$\mathrm{Y}=+17,51+0,10 \mathrm{~A}-0,69 \mathrm{~B}+0,14 \mathrm{AB}$

$\mathrm{A}=$ Aristoflex ${ }^{\circledR}$ AVC; $\mathrm{B}=$ propilen glikol; dan $\mathrm{AB}=$ interaksi antara komponen $\mathrm{A}$ dan $\mathrm{B}$

Hasil koefisien faktor $(+0,10)$ menunjukkan Aristoflex ${ }^{\circledR}$ AVC mempunyai pengaruh peningkatan nilai SPF. Hal ini serupa dengan penelitian Ivaniuk dkk. (2018) bahwa sampel dengan konsentrasi Aristoflex ${ }^{\circledR}$ AVC 1,5\% memiliki parameter reologi yang optimal dapat memberikan ketersediaan bahan aktif biologis yang tinggi. Ekstrak rimpang kunyit digunakan sebagai bahan dalam sediaan gel. Menurut Garg dkk. (2017), rimpang kunyit (Curcuma domestica) mengandung senyawa kurkumin sebagai zat aktif skin photoaging.

Koefisien faktor interaksi Aristoflex® AVC dan propilen glikol adalah $+0,14$ bermakna meningkatkan nilai SPF. Menurut Bayere dkk. (2003) bahwa ikatan hidrogen adalah interaksi utama antara bahan aktif tabir surya dan pelarut. Pelarut berinteraksi dengan ujung karbonil dari masing-masing molekul melalui interaksi ikatan hidrogen, memperluas konjugasi dan menstabilkan struktur elektronik. Selain itu, walaupun propilen glikol dapat menguap perlahan, namun karena penambahan polimer dapat menekan pengeringan film (Binks dkk., 2016). Contour plot (Gambar 5) menggambarkan peningkatan nilai SPF akan semakin terlihat pada konsentrasi Aristoflex ${ }^{\circledR}$ AVC yang tinggi dan dan propilen glikol yang rendah. Aristoflex® AVC level bawah dan propilen glikol level atas akan menurunkan nilai SPF. Hal ini dapat disimpulkan bahwa Aristoflex ${ }^{\circledR}$ AVC dan propilen glikol memberikan pengaruh pada respon SPF.
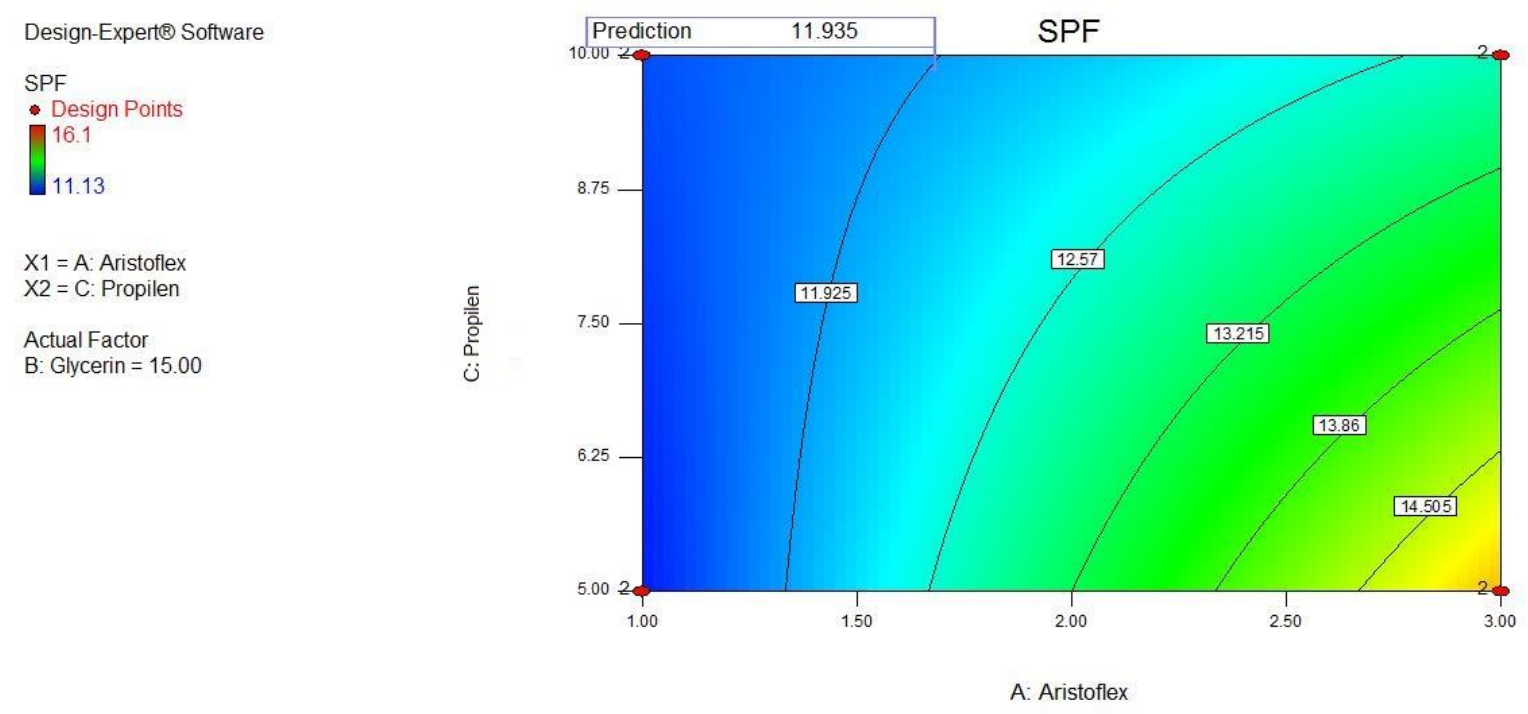

Gambar 5. Contour plot Aristoflex ${ }^{\circledR}$ AVC dan propilen glikol SPF sediaan gel ekstrak rimpang kunyit 


\section{Penentuan formula optimum gel}

Nilai desirability merupakan nilai fungsi tujuan optimasi yang menunjukkan kemampuan program untuk memenuhi keinginan berdasarkan kriteria yang ditetapkan pada produk akhir. Nilai desirability yang semakin mendekati nilai 1,0 menunjukkan kemampuan program untuk menghasilkan produk yang dikehendaki semakin sempurna. Tujuan optimasi bukan untuk memperoleh nilai desirability 1,0 namun untuk mencari kondisi terbaik yang mempertemukan semua fungsi tujuan (Raissi \& Farzani, 2009). Untuk mencari formula optimum maka dibuat superimposed contour plot dengan menggabungkan masing-masing contour plot. Berdasarkan Gambar 6 diketahui bahwa daerah berwarna kuning menggambarkan prediksi daerah optimum formula gel ekstrak rimpang kunyit dengan respon yang diinginkan.

Hasil optimasi memberikan proporsi Aristoflex ${ }^{\circledR}$ AVC 1,68\% dan propilen glikol 9,87\% dan nilai desirability sebesar 0,762 merupakan formula optimum dengan pendekatan desain faktorial diolah dengan Design Expert 7.1.5 sehingga diperoleh nilai daya sebar $5,1 \mathrm{~cm}$, daya lekat 2,018 detik, viskositas $110,008 \mathrm{dPas}$, dan nilai SPF 11,935.

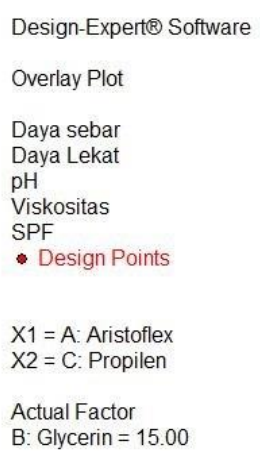

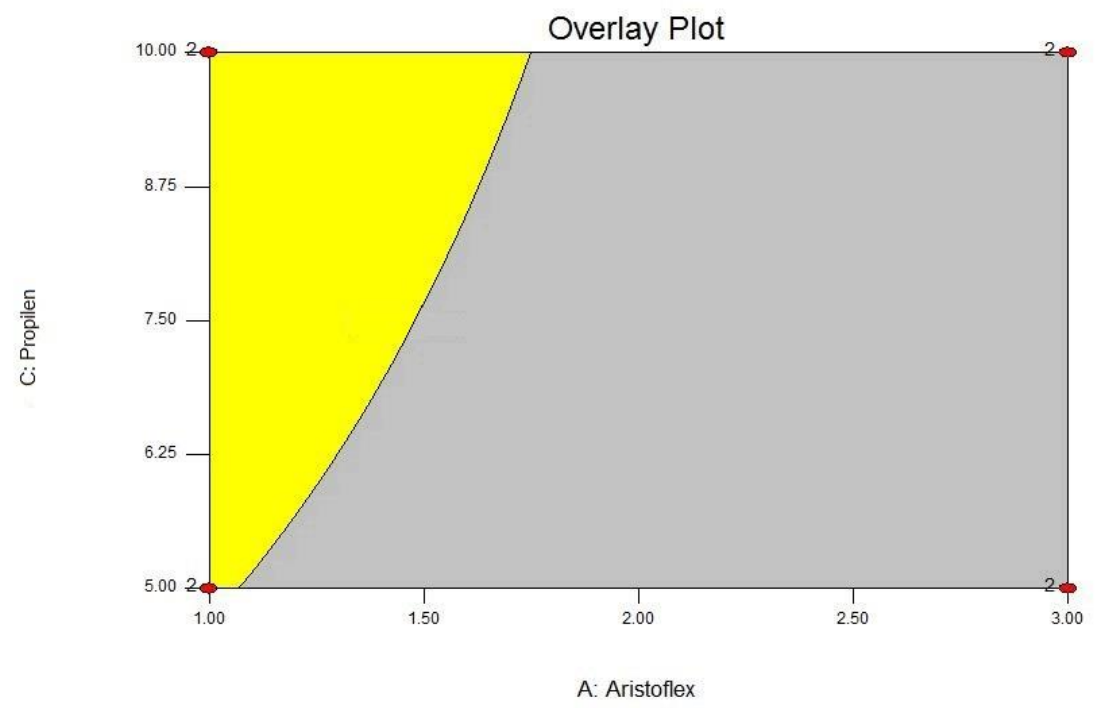

Gambar 6. Superimposed contour plot gel

\section{KESIMPULAN}

Kombinasi Aristoflex ${ }^{\circledR}$ AVC dan propilen glikol memberikan pengaruh pada sifat fisik sediaan gel ekstrak rimpang kunyit. Proporsi Aristoflex® AVC $1,68 \%$ dan propilen glikol 9,87\% merupakan formula optimum gel ekstrak rimpang kunyit dengan pendekatan desain faktorial yang menghasilkan nilai daya sebar $5,1 \mathrm{~cm}$, daya lekat 2,018 detik, viskositas 110,008 dPas, dan nilai SPF 11,935. Kombinasi Aristoflex® AVC dan propilen glikol memberikan pengaruh pada daya sebar, daya lekat, viskositas, dan nilai SPF yang dihasilkan sediaan gel ekstrak rimpang kunyit.

\section{UCAPAN TERIMA KASIH}

Zenith Group dan PT. Tri Raharja atas bantuan bahan baku.

\section{DAFTAR PUSTAKA}

Adithi, P., Arshad, B. K. \& Roopesh, S. K. (2017). Broad Spectrum UVA \& UVB Photoprotectants: an Overview. Journal of Pharmaceutical Research; 16; 113-147.

Anggraeni, C. A. (2008). Pengaruh Bentuk Sediaan Krim, Gel, dan Salep terhadap Penetrasi Aminofilin sebagai Antiselulit secara In Vitro Menggunakan Sel Difusi Franz. Skripsi; Fakultas Matematika dan Ilmu Pengetahuan Alam Departemen Farmasi Universitas Indonesia, Depok.

Bayere, L., Yarasi, S. \& Loppnow, G. R. (2003). Solvent Effects on Sunscreen Active Ingredients Using Raman Spectroscopy. Journal of Raman Spectroscopy; 34; 743-750.

Binks, B. P., Brown, J., Fletcher, P., Johnson, A. J., Marinopoulos, I., Crowther, J. M. \& Thompson, M. A. 2016. Evaporation of Sunscreen Film: How the UV Protection Properties Change. Applied Material and Interfaces; 8; 13270-13281.

Boer, Y. B., May, V. F. \& Brun, P. L. (2015). Practical Pharmaceutics: an International Guideline for the 
Preparation, Care, and Use of Medicinal Products. New York: Springer International Publishing.

Cho, J. W., Park, K., Kweon, G. R., Jang, B. C., Baek, W. K., Suh, M. H., Kim, C. W., Lee, K. S. \& Suh, S. I. (2005). Curcumin Inhibits the Expression of COX-2 in UV-B Irradiated Human Keratinocytes (HaCaT) by Inhibiting Activation of AP-1: p38 MAP Kinase and JNK as Potential Upstream Targets. Experimental and Molecular Medicine; 37; 186-192.

Contreras, M. D. \& Sanchez, R. (2002). Application of a Factorial Design to the Study of the Flow Behavior, Spreadibility, and Transparency of a Carbopol ETD 2020 Gel. International Journal of Pharmaceutics; 234; 149-157.

Dana, S. F., Nguyen, D., Kochhar, J. S., Liu, X. \& Kang, L. (2013). UV-curable Pressure Sensitive Adhesive Films: Effects of Biocompatible Plasticizers on Mechanical and Adhesion Properties. Royal Society of Chemistry; 9; 62706281.

Garg, A., Aggarwal, D., Garg, S. \& Singla, A. K. (2002). Spreading of Semisolid Formulations (an update). Pharmaceutical Technology; 26; 84-105.

Ivaniuk, O. I., Yarnyakh, T. G., Hrudko, V. O. \& Kovalevska, I. V. (2018). Determination of Vaginal Gel Composition of the Basis of Biopharmaceutical and Rheological Researches. Annals of Mechnikov Institute; 4; 43-47.

Juwita, A. P., Yamlean, P. V. \& Edy, H. J. (2013). Formulasi Krim Ekstrak Etanol Daun Lamun (Syringodium isoetifolium). Jurnal Farmasi Indonesia; 2; 8-12.

Lee, S. Y., Pung, Y. Y., Khor, B. K., Kong, W. E., Tan, C. T. \& Teo, S. Y. (2016). Lipid-based Delivery System for Topical Phenytoin. Journal of Applied Pharmaceutical Science; 6; 14-20.

Liu, X., Zhang, R., Shi, H., Li, X., Li, Y., Taha, A. \& $\mathrm{Xu}$, C. (2018). Protective Effect of Curcumin Against Ultraviolet a Irradiation-Induced Photoaging in Human Dermal Fibroblasts. Molecular Medicine Report; 17; 7227-7237.

Mokodompit, A. N., Hosea, J. E. \& Weny, W. (2013). Penentuan Nilai Sun Protective Factor (SPF) secara In Vitro Krim Tabir Surya Ekstrak Etanol Kulit Alpukat. Jurnal Ilmiah Farmasi; 2; 83-85.

Murphy, G. (2014). Photocancerogenesis Strategies For Prevention. Proceedings; 2nd European Course of Photodermatology, Dublin.

Peneva, P., Andonova, V., Dimcheva, T. \& Kassarova, M. (2017). Technological and Biopharmaceutical
Characterization of Carbopol-Based Ketoprofen Emulgels. Indian Journal of Pharmaceutical Education and Research; 52; 212-217.

Raissi, S. \& Farzani, R. E. (2009). Statistical Process Optimization Through Multi-Response Surface Methodology. World Academy of Science, Engineering and Technology; 51; 267-271.

Rathod, H. J. \& Mehta, D. P. (2015). A Review on Pharmaceutical Gel. Acta Scientifica International Journal of Pharmaceutical Science; 1; 33-47.

Rhys, N. H., Gillams, R. J., Collins, L. E. \& Callear, S. K. (2016). On the Structure of an Aqueous Propylene Glycol Solution. The Journal of Chemical Physics; 145; 224504.

Silalahi, K. N., Fahrurroji, A. \& Kusharyanti, I. (2015). Optimasi Formula Losio dengan Kombinasi Zat Aktif Vitamin C dan Vitamin E sebagai Antipenuaan Kulit Serta Uji Stabilitas Losio. Jurnal Mahasiswa Farmasi Fakultas Kedokteran UNTAN; 3; 1-17.

Singh, S., Govind, M. \& Bothara, S. B. (2013). A Review on In Vitro-In Vivo Mucoadhesive Strength Assessment. Pharm Tech Medica; 1; 221-229.

Sinko, P. J. (2011). Martin's Physical Pharmacy and Pharmaceutical Sciences: Physical Chemical and Biopharmaceutical Principles in the Pharmaceutical Sciences. Philadelphia: Lippincott Williams and Wilkins.

Skotarczak, K., Osmola-Mankowska, Lodyga, M., Polanska, M. \& Adamski. (2015). Photoprotection: Facts and Controversies. European Review for Medical and Pharmacological Sciences; 19; 98-112.

Syamsuni, H. (2005). Farmasetika Dasar dan Hitungan Farmasi. Jakarta: Penerbit Buku Kedokteran EGC.

Varges, P. R., Costa, C. M., Fonseca, B. S., Naccache, M. F. \& Mendes, P. R. (2019). Rheological Characterization of Carbopol ${ }^{\circledR}$ Dispersions in Water and in Water/Glycerol Solutions. Fluids; 4; $1-20$.

Wardiyah, S. (2015). Perbandingan Sifat Fisik Sediaan Krim, Gel, dan Salep yang Mengandung Etil pMetoksisinamat dari Ekstrak Rimpang Kencur (Kaempferia galangal Linn.). Skripsi; Fakultas Kedokteran dan Ilmu Kesehatan UIN Syarif Hidayatullah, Jakarta.

Yati, K., Mahdi, J., Misri, G., Mardiastuti \& Lusi, P. D. (2018). Pengaruh Variasi Konsentrasi Hydroxy 
Propyl Methyl Cellulose (HPMC) terhadap Stabilitas Fisik Gel Ekstrak Tembakau (Nicotiana tabaccum L.) dan Aktivitasnya terhadap Streptococcus mutans. Pharmaceutical Sciences and Research; 5; 133-141.
Yuliani, S. H. (2010). Optimasi Kombinasi Campuran Sorbitol, Gliserol, dan Propilen Glikol dalam Gel Sunscreen Ekstrak Curcuma mangga. Majalah Farmasi Indonesia; 21; 83-89. 